\title{
Friction Hydro Pillar Processing: Characteristics and Applications
}

\author{
Diogo Trento Buzzatti ${ }^{1}$, Jonas Trento Buzzatti ${ }^{1}$, Rafael Eugenio dos Santos ${ }^{1}$, Fabiano Mattei ${ }^{1}$, Mariane Chludzinski ${ }^{1}$, \\ Telmo Roberto Strohaecker ${ }^{1}$
}

${ }^{1}$ Laboratório de Metalurgia Física - LAMEF, Universidade Federal do Rio Grande do Sul - UFRGS, Porto Alegre, RS, Brasil.

Received: 27 Aug., 2015

Accepted: 13 Oct., 2015

E-mail: telmo@demet.ufrgs.br (TRS)
This is an Open Access article distributed under the terms of the Creative Commons Attribution Non-Commercial License which permits unrestricted non-commercial use, distribution and reproduction in any medium provided the original work is properly cited.
Abstract: The friction welding process is shown as an effective alternative compared to the conventional methods of joining materials, in particular Friction Hydro Pillar Processing (FHPP). With the use of automated equipment joints are produced with reliable quality and repeatability, making it possible to follow in real time the welding process. The study of the application of this process in different materials proves its use in production systems. The development of several lines of research shows that even varying materials and geometry of joints with at least $20 \mathrm{~mm}$ deep in thick plates, the processing time remains less than 6 (six) minutes. Furthermore, as a result joints with suitable metal/mechanical properties are made with low production cost and high productivity, even for materials with low weldability and with different characteristics. In this work will be presented various materials joined by FHPP, as well as its advantages and applicability.

Key-words: Repair welding process; Friction Hydro Pillar Processing; Ferrous materials.

\section{Processo de Soldagem por Friç̧ão com Pino Consumível: Características e Aplicações}

Resumo: O processo de soldagem por fricção mostra-se como alternativa eficaz frente aos métodos convencionais de união de materiais, em especial a soldagem por fricção com pino consumível (Friction Hydro Pillar Processing). Com uso de equipamentos automatizados são produzidas juntas com qualidade e repetibilidade confiável, tornando possível acompanhar em tempo real o processo de soldagem. O estudo da aplicação desse processo em diferentes materiais comprova a sua utilização em sistemas produtivos. O desenvolvimento de diversas linhas de pesquisas mostra que mesmo variando materiais e geometria o tempo de processamento de juntas soldadas com no mínimo $20 \mathrm{~mm}$ de profundidade em chapas espessas se mantem inferior a 6 (seis) minutos. Além disso, têm-se como resultado juntas com propriedades metal/mecânica adequadas, com custo de produção reduzido e alta produtividade, mesmo para materiais com baixa soldabilidade e com características dissimilares. Neste trabalho serão apresentados diversos materiais unidos por FHPP, bem como sua aplicabilidade e vantagens.

Palavras-chave: Processo de soldagem para reparo; Soldagem por friç̧ão com pino consumível; Materiais ferrosos.

\section{Introduction}

The evolution of joining techniques had great progress with the technological industrial development. Welding by fusion, in particular, it is ahead to several processes due to the high level of investment and research. Its uses cover various areas of the world market with appropriate methods and procedures for every situation. The knowledge of this technique demonstrated that there are inherent characteristics to the process that must be contoured to achieve the desired goals. As this process depends upon the fusion of the materials, the careful with the elements of alloy and heat imput are required. To perform the welding, procedures were instituted order to avoid the defects associated with fusion: solidification cracking, segregation of alloying elements, solubility of gases, formation of undesirable phases and overheating. Also is recommended the implementation of inspection methods, tests and qualification training. Given this scenario the demand for processes with innovative technologies presents itself as an alternative to fusion welding methods.

In this context the friction processes are an alternative, as they occur in the solid state. The joining of the materials is produced from heat generated by friction between the parts subjected to an applied force. The development of different friction techniques were 
encouraged due to the reduced welding time, automation, repetability, operational safety and better properties of the welded joint.

Friction Hydro Pillar Processing (FHPP) was developed to meet the repair area and maintenance repair of the structures. This process is performed by applying an axial force on a rotated rod within a cavity machined earlier. Through the intimate contact friction, the materials are plasticized and the joint is accomplished (Figure 1a). At the end of the process the excess of the plasticized material, named flash, is extracted [1,2].

For being a process that does not need gas protection and without generating fumes and waste gases, it is possible to produce joints in different environments, underwater or in aggressive atmosphere. The advance of technology and the development of welding equipment made possible the repair of cracks with length greater than the diameter of the consumable rod. The evolution of this method became known as Stitch Weld, where the rods are sequentially applied in a overlapping to cover the full extent of the defect. For each rod applied a new cavity is machined (Figure 1b) [3].
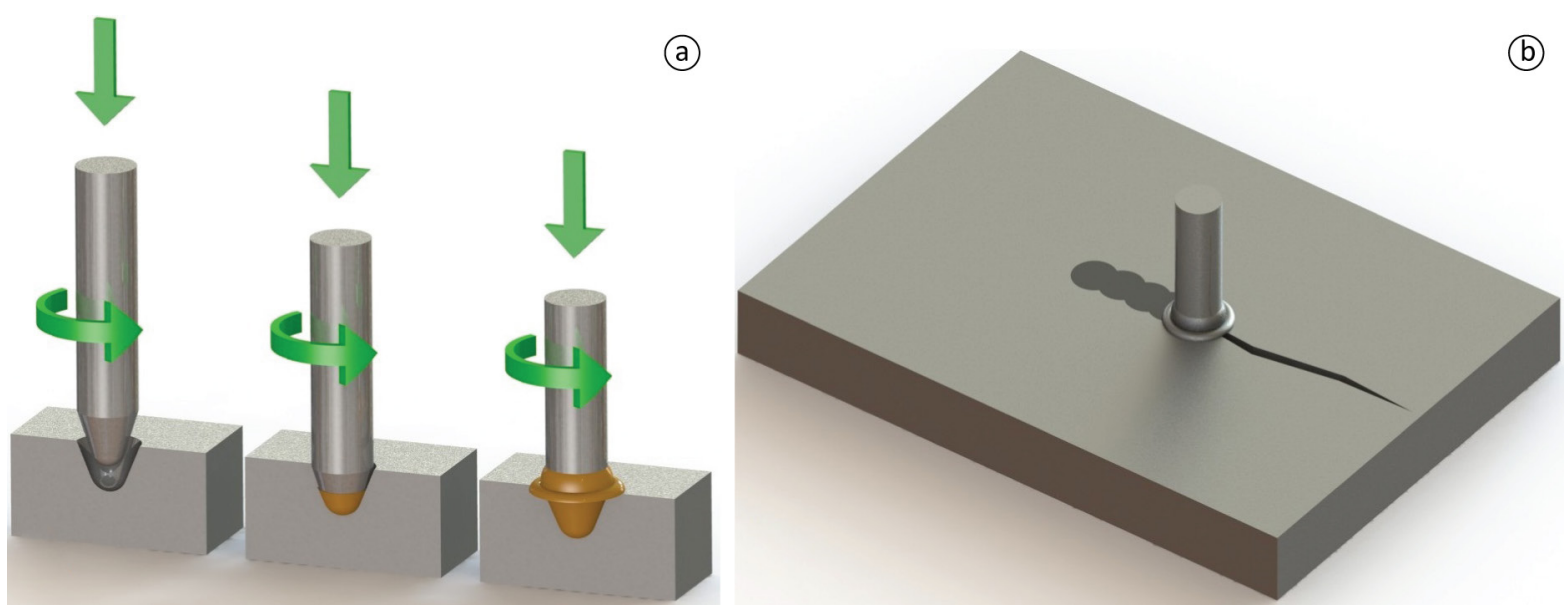

Figure 1. Friction Hydro Pillar Processing (a) and Stitch Welding (b).

In the world, few institutions have explored this technique [4-10]. The Physical Metallurgy Laboratory (LAMEF) from the Federal University of Rio Grande do Sul (UFRGS) started in 2007 studies in friction welding and has since conducted several studies on the subject. Currently is exploring the development of equipment, processing, training, joint analysis, tests and destructive and non-destructive test [11-17]. Also studies related to materials, geometries and process parameter are carry out, as well as the persuit for the insertion of this method in the metal/mechanical industry with scientific and technological support. In this work will be presented various materials joined by FHPP. The joints produced with similar and dissimilar materials were evaluated by different methods performed with equipment available in LAMEF. For each material studied was performed a serious of tests and assays relevant for evaluation, however will be presented only the most relevant results according to their applicability.

\section{Friction Welding Equipment}

The scientific production of LAMEF in the friction welding processes has made great advances with the development of equipment and machinery with adaptive operating characteristics. Such characteristics provide the application of a broad range capable of joining materials with metal/mechanical properties and variable geometries. Welding is fully automated and the control software is used to allow instant viewing of the evolution of process parameters, enabling the assessment of pre-established conditions. The MPF 1000 and MSA 50 machines were built with acquisition and monitoring systems online ensuring control of the process (Figures 2 and 3 ). The assembling of one more equipment is being finalized with intermediate capacity of $250 \mathrm{kN}$ and $3000 \mathrm{rpm}$. 

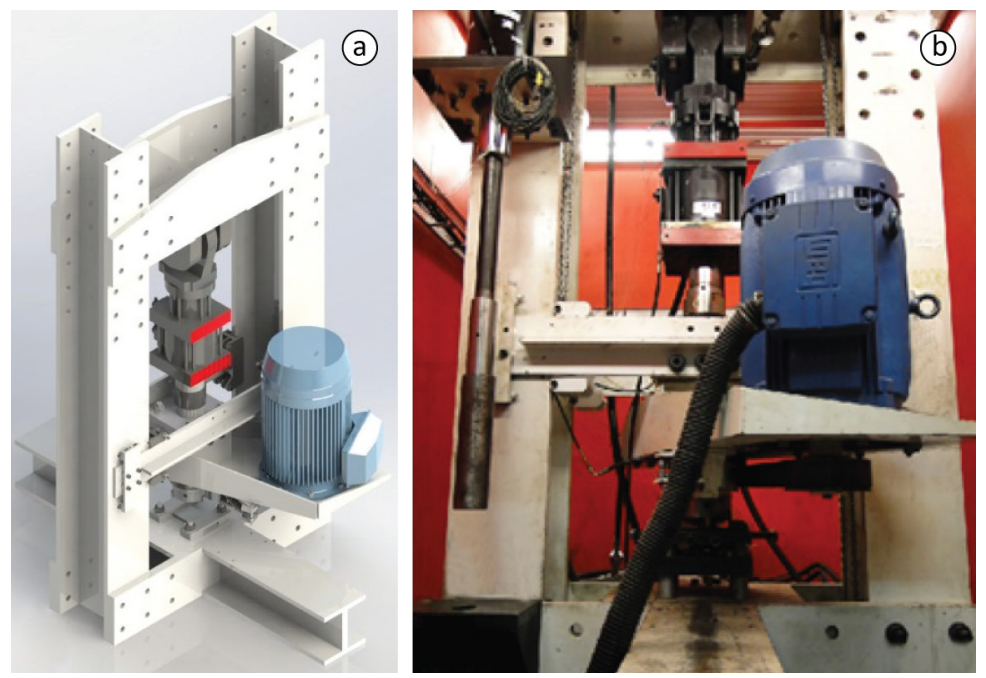

Figure 2. Project (a) and MPF 1000 (b), capacity of 1000 kN and $2000 \mathrm{rpm}$.



Figure 3. Project (a) and MSA 50 (b), capacity of $50 \mathrm{kN}$ and $8000 \mathrm{rpm}$.

\subsection{Welding parameters}

The key process control parameters are: rotation speed, burn off, axial and forging force. The rotation speed is the velocity printed on the rod, the axial force and forging are the axial forces applied to the rod and the burn off is the pre-determined vertical displacement during which the rod will be processed. The acquired data can be seen as graphic (Figure 4) where it highlights key information such as: axial and forging force, burn off, total welding time and processing time. 


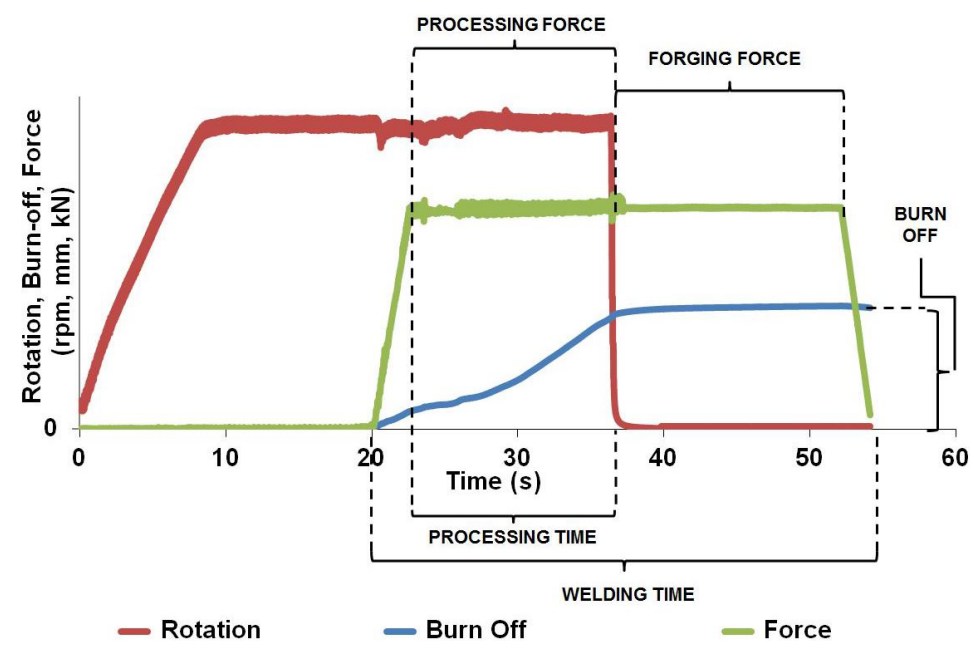

Figure 4. Characteristic graph of welding parameters.

Friction joints have characteristics regions resulting from the influence of welding parameters and also from the metallurgical and mechanical properties involved. For a joint produced by FHPP it is commonly observed: base material (BM), flash, heat affected zone (HAZ) and thermo-mechanical affected zone (TMAZ) (Figure 5).

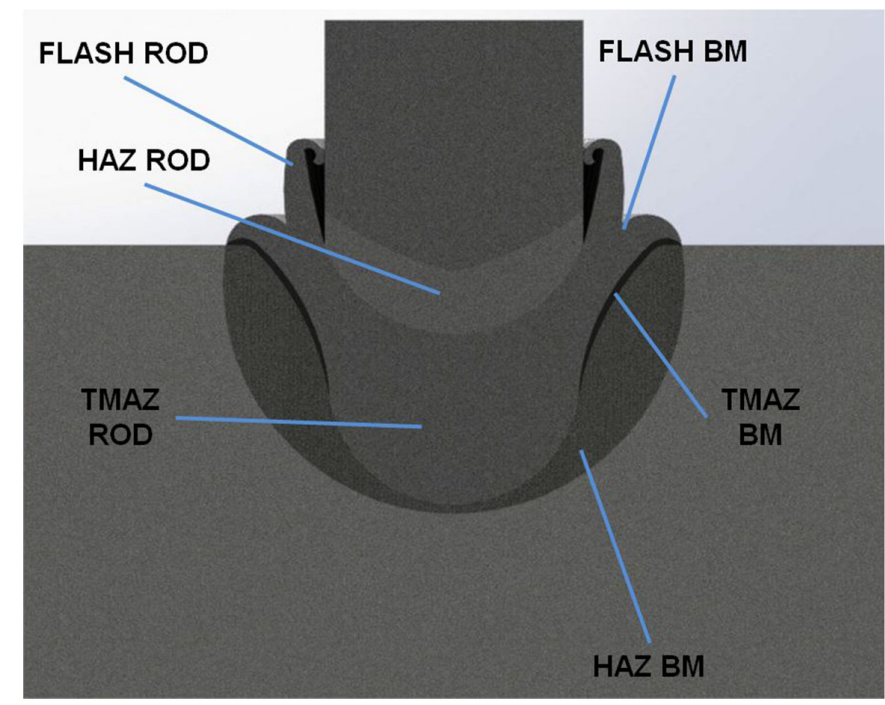

Figure 5. Region characteristics of a friction joint.

\subsection{Geometry}

Along the years many papers were published with studies related to the parameters and welding materials $[1,9,11]$. However it was found that the geometry of the components rod and cavity machined directly affects the final characteristics of the joint, being as important as the welding parameters. The geometry of the components can be altered by varying the diameters, the angles of the conic sections of the rod and hole and the surfaces corresponding inicial contact to the hole botton and the tip of the rod (Figure 6). The main influences of geometry are directly related to the effectiveness of filling and the amount of heat generated at the contact surface. This is due to factors such as the resulting torque, stress variation applied between the start and end of the process, heat flow and plastic material. 


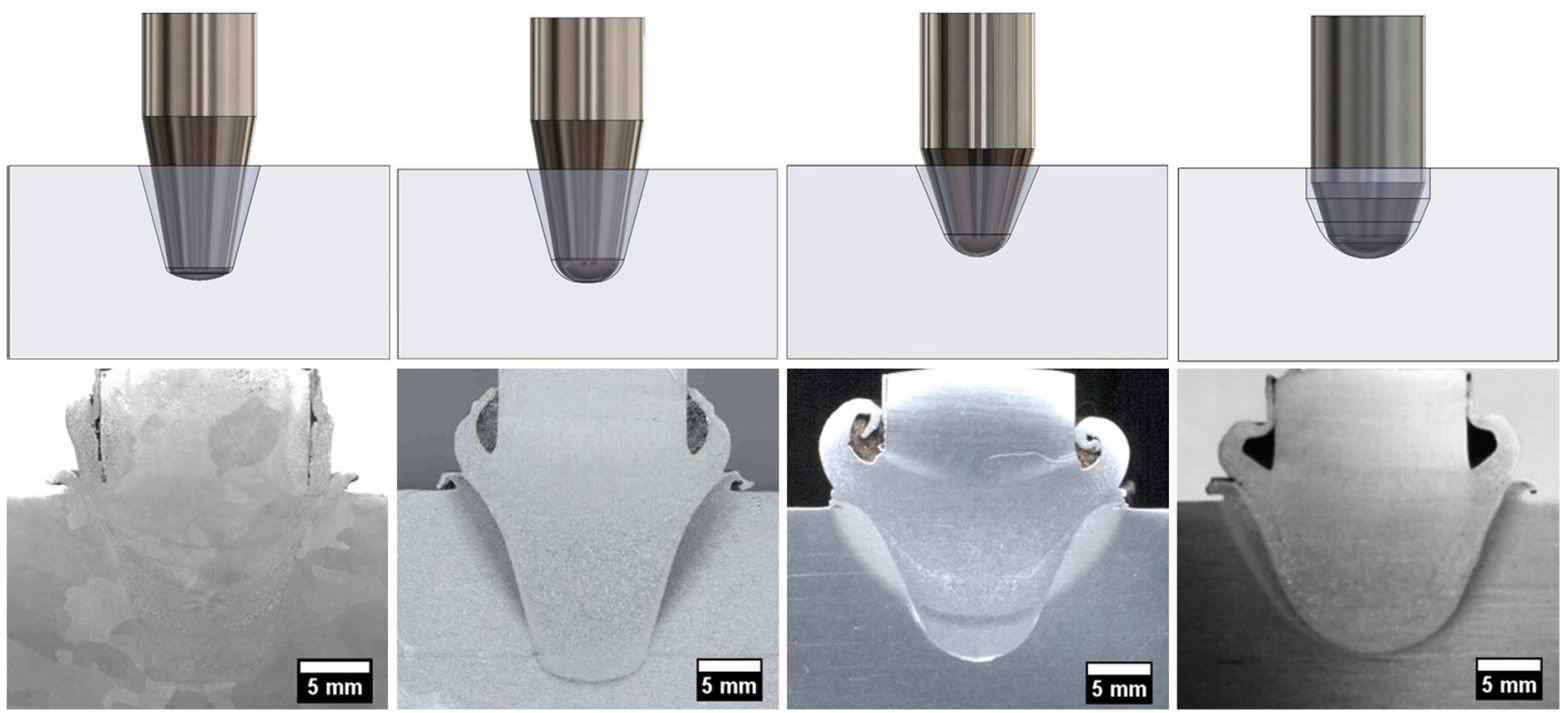

Figure 6. Macrographs of different geometries studied.

\section{Welded Materials}

\subsection{Low alloy steel}

The application of friction welding process in commercial steels showed satisfactory results. The joints were carried out with rods and bases produced by low alloy steel and subjected to bend test. This assessment method allows checking the joint and ductility of the welded area. The specimens were extracted from the joint in order to submit all the interface region to mechanical stress and they were bent to 180 degrees without showing cracks or defects (Figure 7).
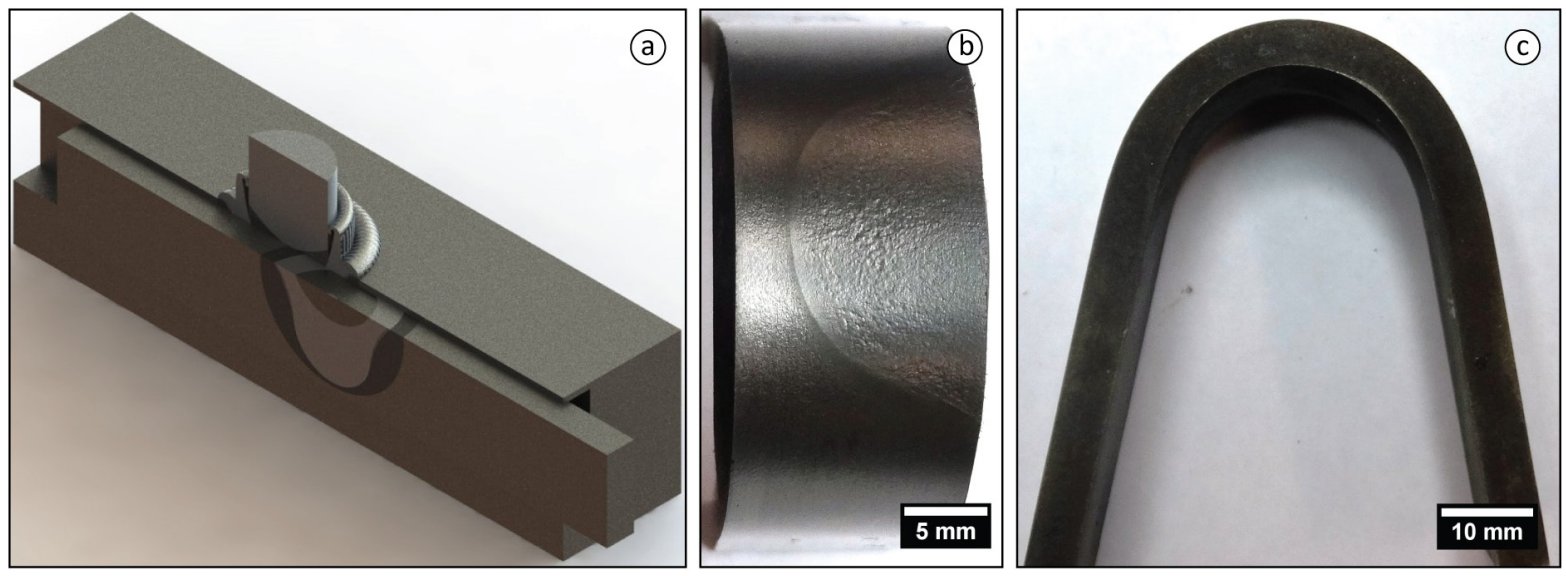

Figure 7. Withdrawal position of the samples for bending test (a) and results (b and c).

\subsection{High Tensile Steel}

\subsubsection{SAE 4140}

The production of joints with high tensile steel materials such rod of SAE 4140 and BM of SAE 1045 presented defect free joints and satisfactory mechanical results for different welding parameters (Figure 8). It was observed martensitic structure with morphological variations resulting from the processing deformation and heat input. In resulting structure was not verified the appearance of dentritic structure and cracks related to volumetric variation. As expected the profile of microhardness Vickers indicated variation in the processed region, where the region of greater hardness was observed in the contact line between rod and base (Figure 9). 

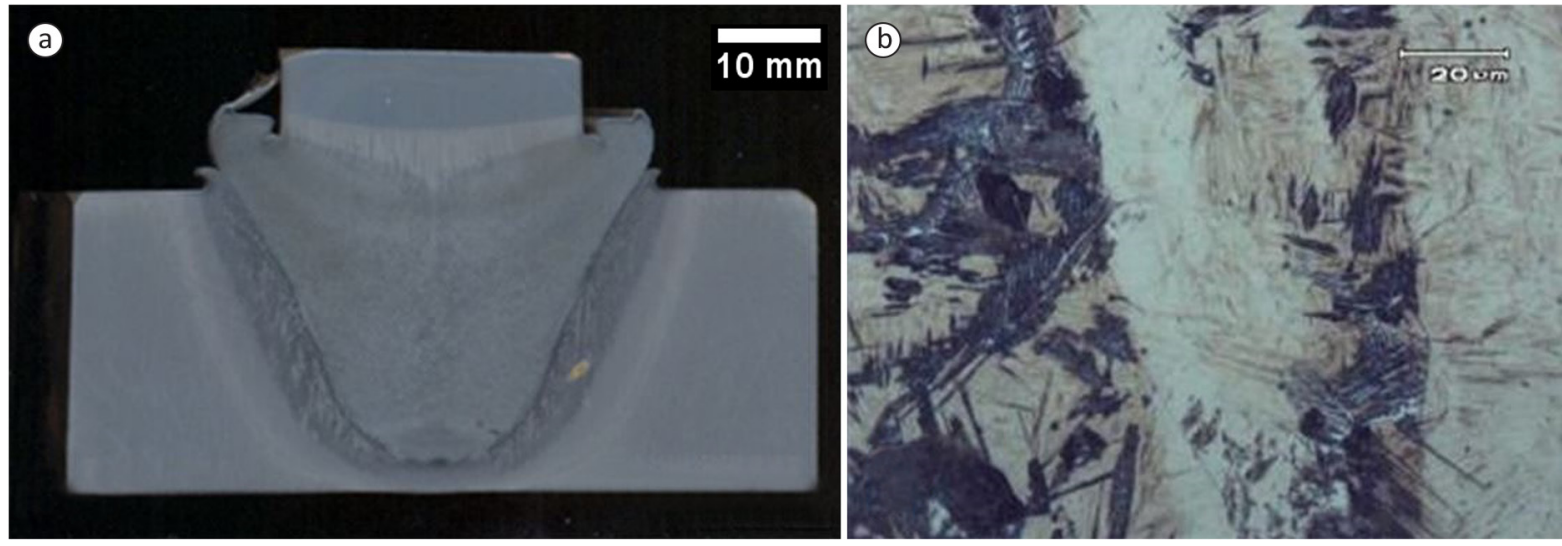

Figure 8. Macrograph of SAE 4140 (a) and metallography of the bonding zone (b).

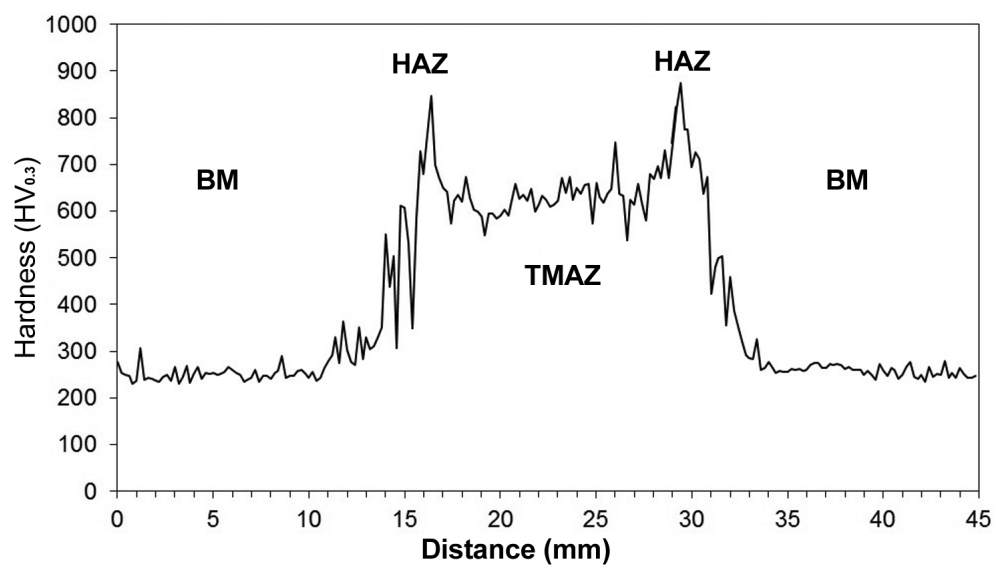

Figure 9. Profile of microhardness.

The mechanical resistance of the joint was assessed by the tensile test. The samples were extracted cross the weld in order to submit the entire region to applied efforts (Figure 10). The weld joint was sectioned into 5 (five) samples, each one comprised a reduced section. The specimen located closer to the inner surface of the joint (CP01) resulted in lower tensile strength $(661 \mathrm{MPa})$ with the fracture occurring within the weld. In others specimens maximum tensile was above $700 \mathrm{MPa}$ and the fracture did not occur in the center nor interface of the weld. Samples CP02 and 03 fractured in the BM and CPO4 and 05 in the Heat Affected Zone of the BM. These results indicate a strong metallurgical bond of the friction joint (Figure 11).
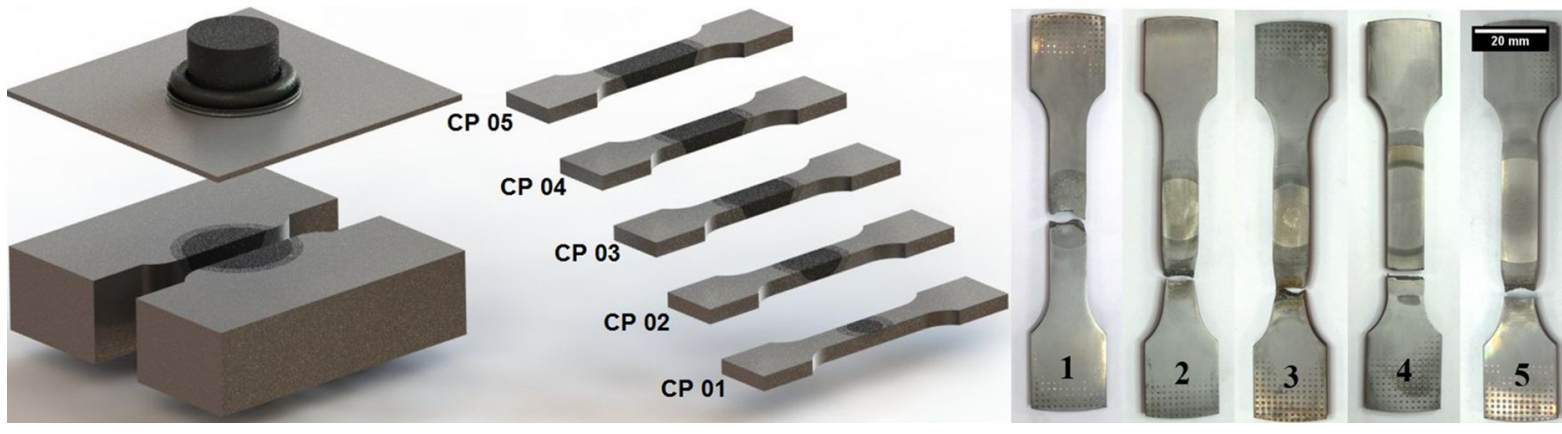

Figure 10. Tensile test specimens. 


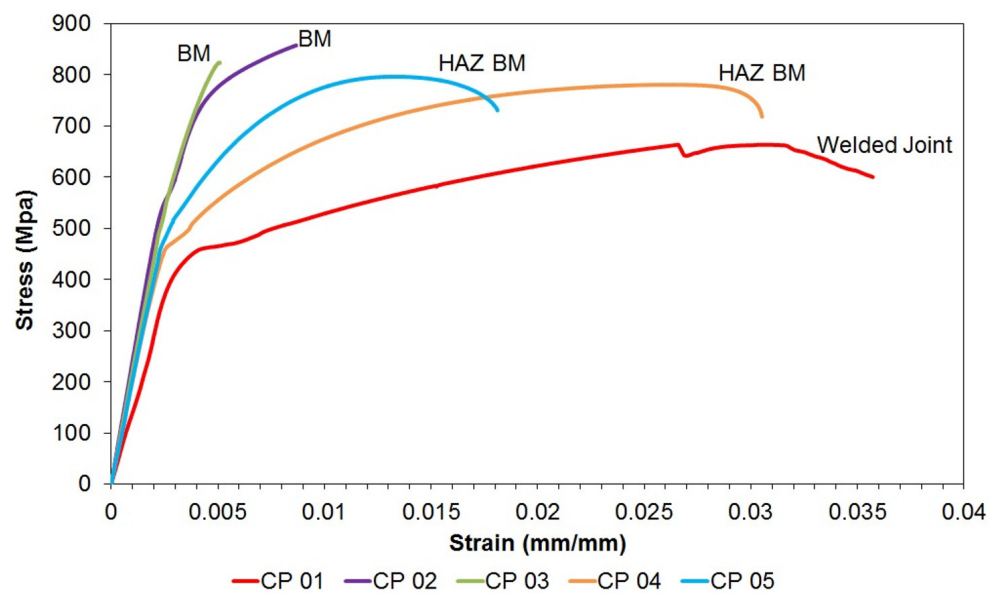

Figure 11. Result of tensile tests.

\subsubsection{SAE 8627}

Continuing the study of the feasibility of repairs FHPP in low weldability materials, the joints were produced with SAE 8627 showed no defects (Figure 12). These materials are widely used in conditions requiring high mechanical strength and good hardenability because they have high content of alloying elements and high carbon equivalent.
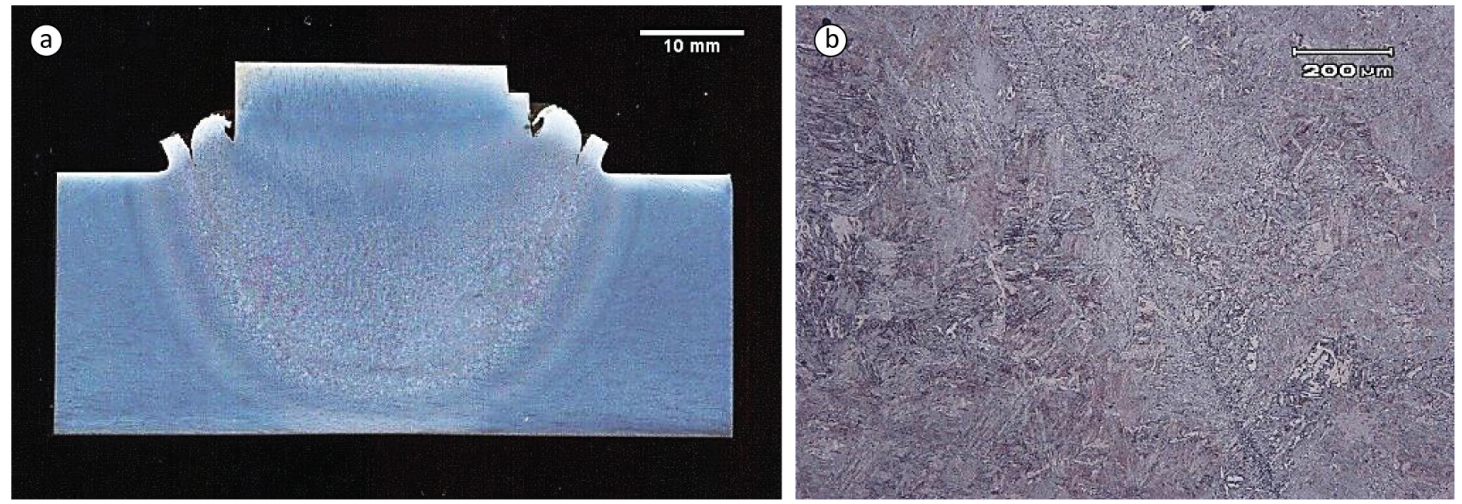

Figure 12. Joint of SAE 8627 (a) and its bonding zone (b).

During the process of welding joints are exposed to high plastic deformation rates and heat extraction. The resulting structure found is martensite originated from refined grains as austenitic, some joints displayed cracks and high hardness (Figure 13).

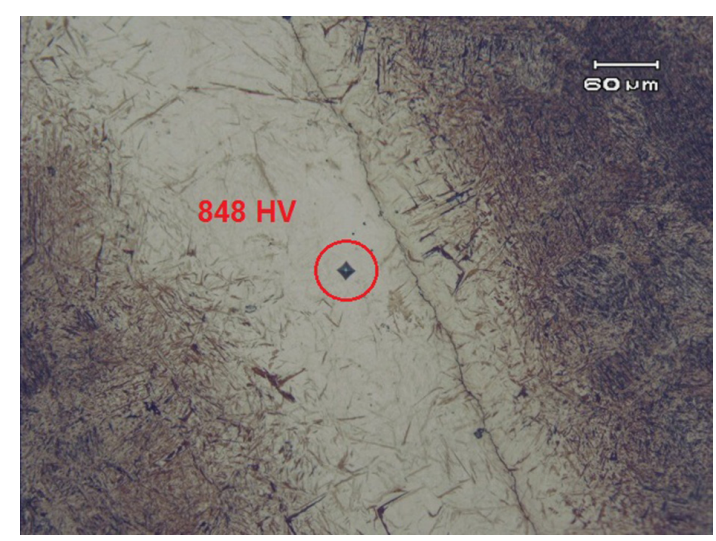

Figure 13. Microstructure of martensite of the bonding zone. 
In order to homogenize the mechanical properties of the material studies were performed by subjecting the joints to thermal treatments. As results defects free welds were obtained and Vickers microhardness mappings illustrate the effect of treatment on the hardness (Figure 14).
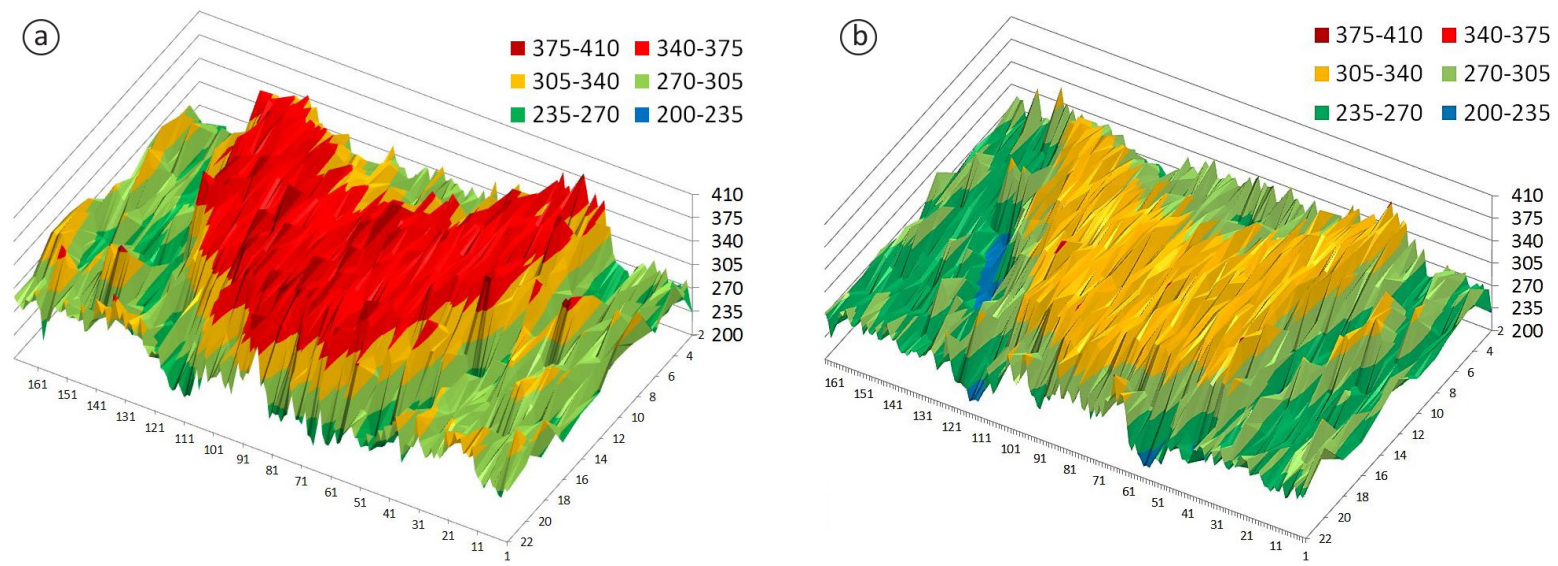

Figure 14. Microhardness mappings showing the effect of heat treatment: with (a) and without (b) subsequent heat treatment.

\subsection{Hot work tool steel}

From the results obtained with low weldability steel, joints were produced with high alloy steels ASTM A 691 (AISI H13). These materials are used for hot work applications as pressure die casting tools, extrusion tools, forging dies, hot shear blades, stamping dies and its welding require judicious procedures such as: pre and post heating, controlled energy input, high cost consumables, etc... The study of the production of friction welded joints of this material showed as a result joints without cracks or defects (Figure 15).

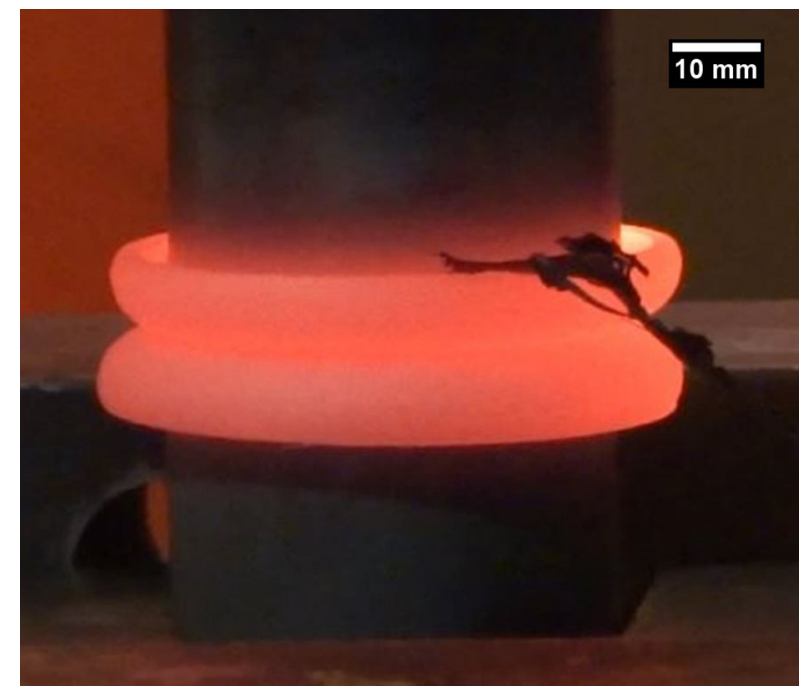

Figure 15. Joint during the welding process.

Friction joints were produced with rod diameter of 2 inches with lower processing time of 1 minute and after the welding process the joints were subjected to heat treatment. The profile of microhardness presented regions with hardness drop in the zone heat affected due to grain growth (Figures 16 and 17). 


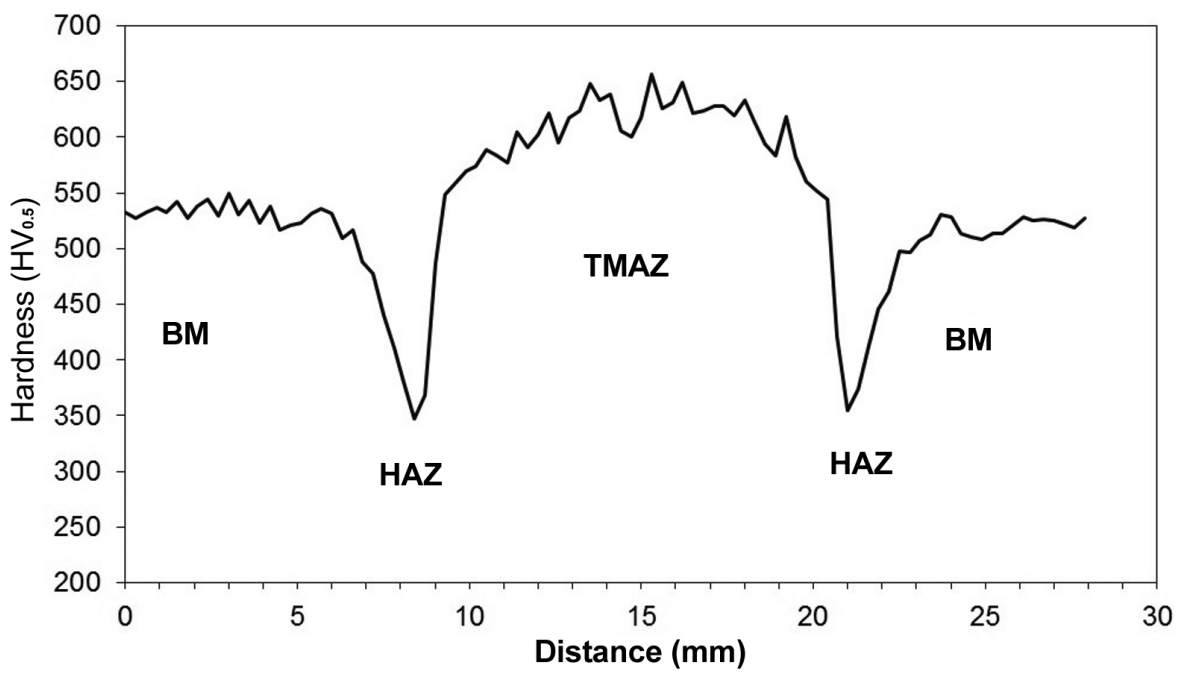

Figure 16. Microhardness profile.

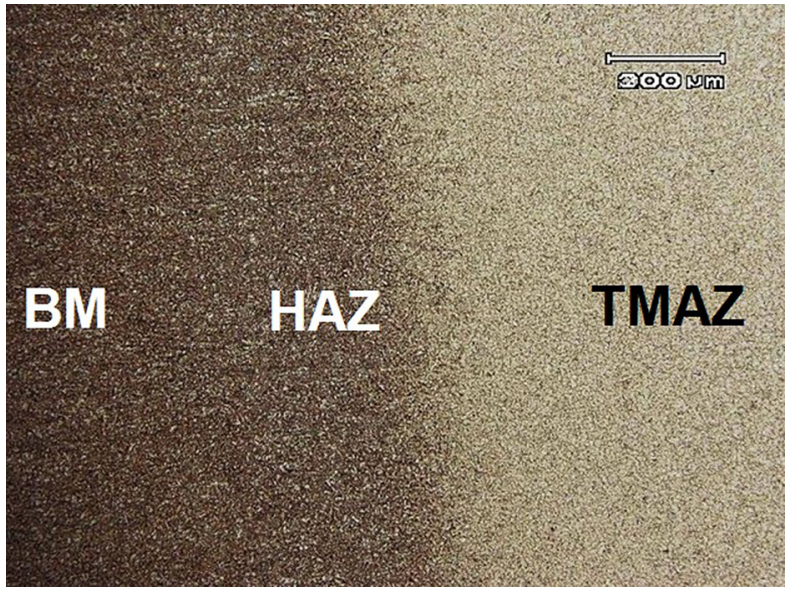

Figure 17. Microstructure of the bonding zone.

\subsection{Cast iron}

Cast iron parts are currently produced all over the world with low production cost and with metal/mechanical characteristics. This material has high carbon content, hindering the completion of welding processes to repair or as an additional process increasing the production cost. The time required to process a joint is 6 (six) minutes without applying additional processes (Figure 18).

\subsection{Stainless steels}

Stainless steels are currently used in various industrial sectors because of its corrosion resistence and good mechanical properties. Each class in which stainless steels are segmented presents chemical composition and microstructure differentiated, affecting, therefore their weldability. The joints produced by BM of duplex stainless steels and rods made of duplex and austenitic stainless steels were analyzed by fracture toughness test (Crack Tip Opening Displacement) at the interface region. As the process produces a welded region of conical shape, it is necessary an innovative methodology of specimen extractions. The choice of a specimen and its positioning in the joint are essential to a correct assessment. Through the use of metallography procedures coupled with precision machining by wire electrical discharge machine can ensure the dimensional accuracy and the correct positioning of the specimen recommended by standards (Figure 19). 

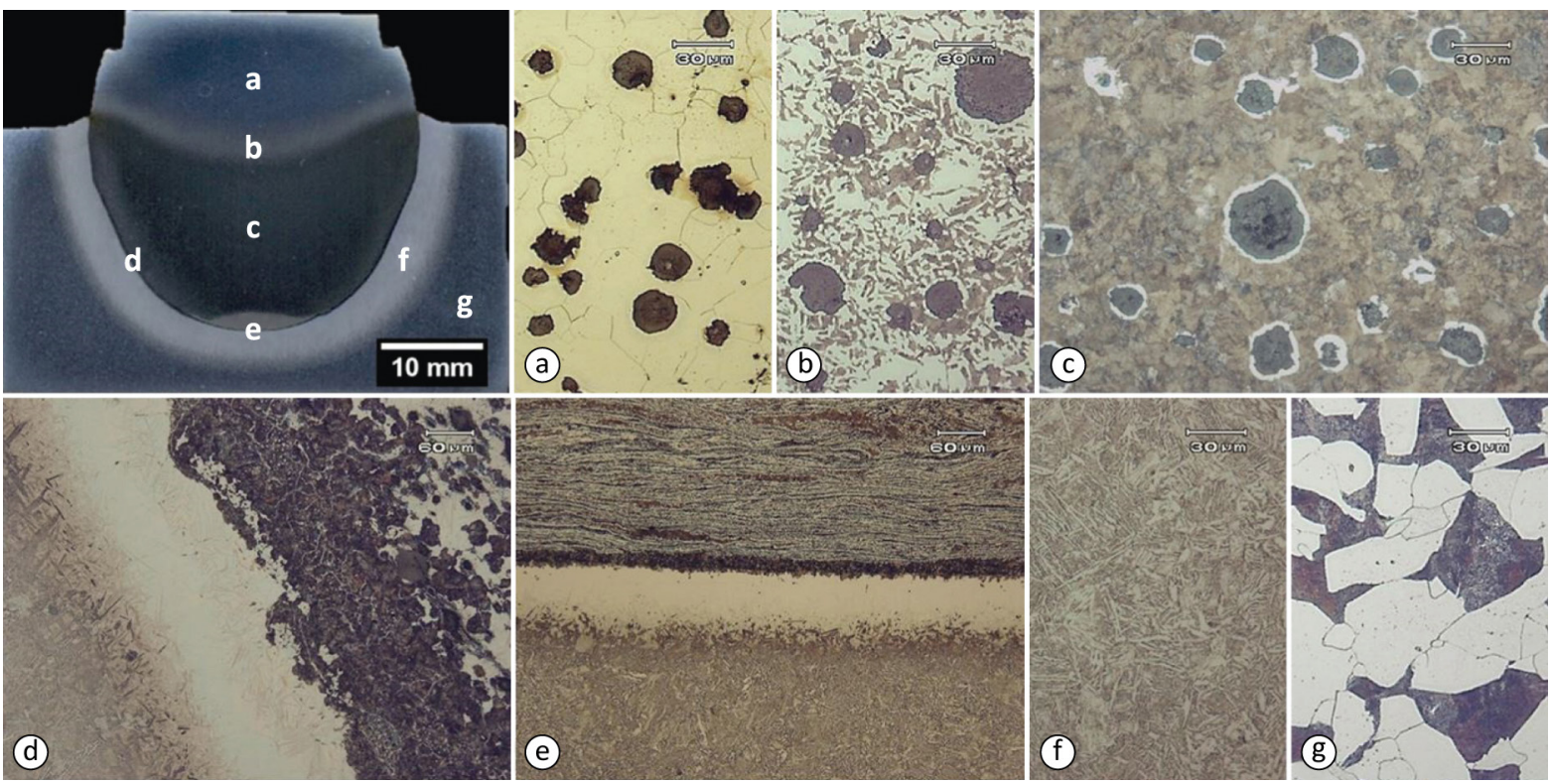

(d)
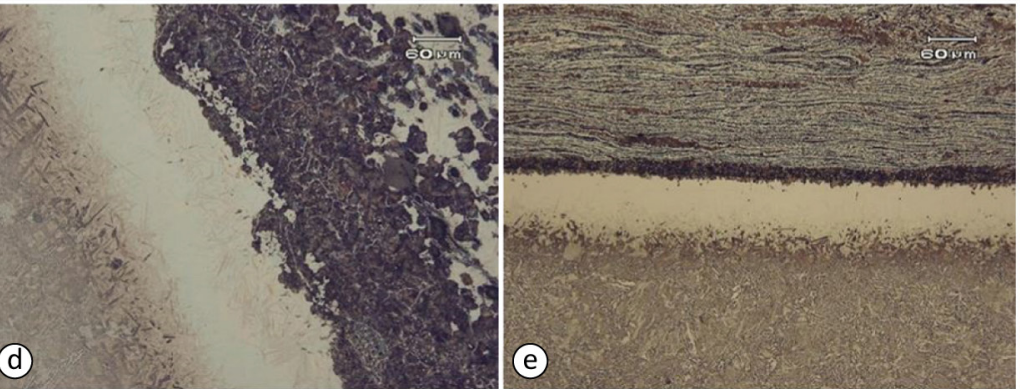

Figure 18. Dissimilar weld joint made from ductile cast iron and SAE 8620. Microstructure of the cast iron rod (a), HAZ of rod (b), TMAZ of rod (c), interface (c and d), HAZ of BM (f) and SAE 8620 BM (g).
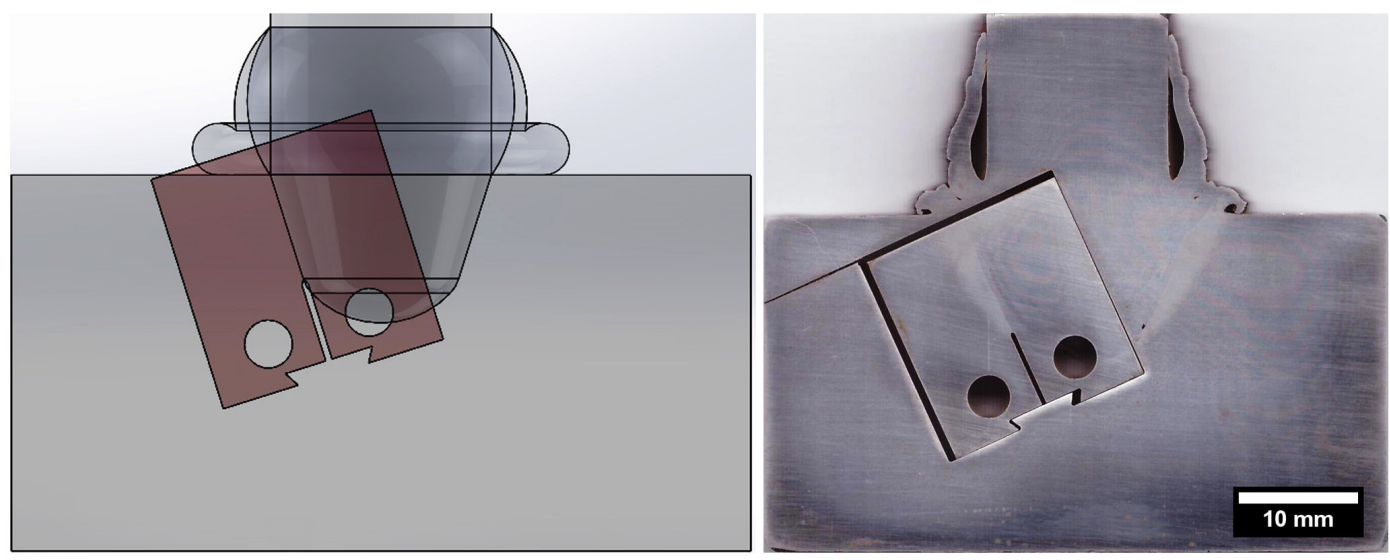

Figure 19. Specimen positioning in the bonding zone.

On duplex stainless steels the short period of welding greatly benefits the final microstructure by maintaining ratio between austenite and ferrite and significant reduction of deleterious phases. During the CTOD tests are obtained the data measured by the fracture strain gauge coupled to a universal testing machine. The results indicated a drop in toughness of the bonding zone due to changing of the morphology of the phases austenite and ferrite. In Figure 20 is presented the crack opening curve due to the applied force and the scanning electron microscope (SEM) fractography analysis with a fully ductile fracture surface.

\section{Underwater Welding}

The application of friction welding process showed to be suitable for underwater applications (Figure 21). Low carbon steel joints were produced using the same welding parameters in and out of the water. During process temperature recording were carry out where it was observed that the joints under water showed minor peaks with higher heat extraction rate (Figure 22). This study revealed that the welding parameters must be evaluated for each application environment and the process is not susceptible to solubilization of the elements of the environment. The elements had a complete filling without crack and defects, both on the air and under water environments. 

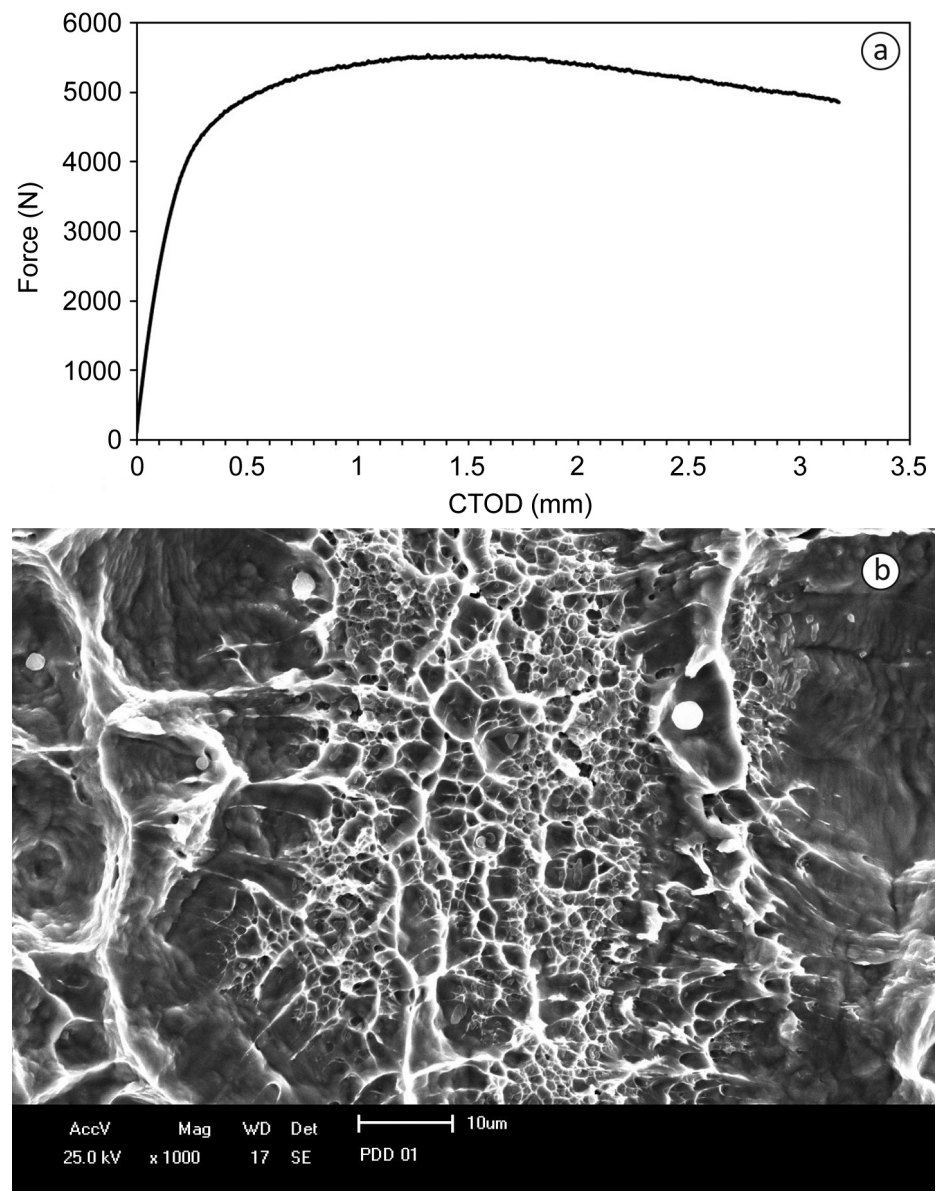

Figure 20. Fracture toughness test (a) and SEM fractography of the fracture surface (b).

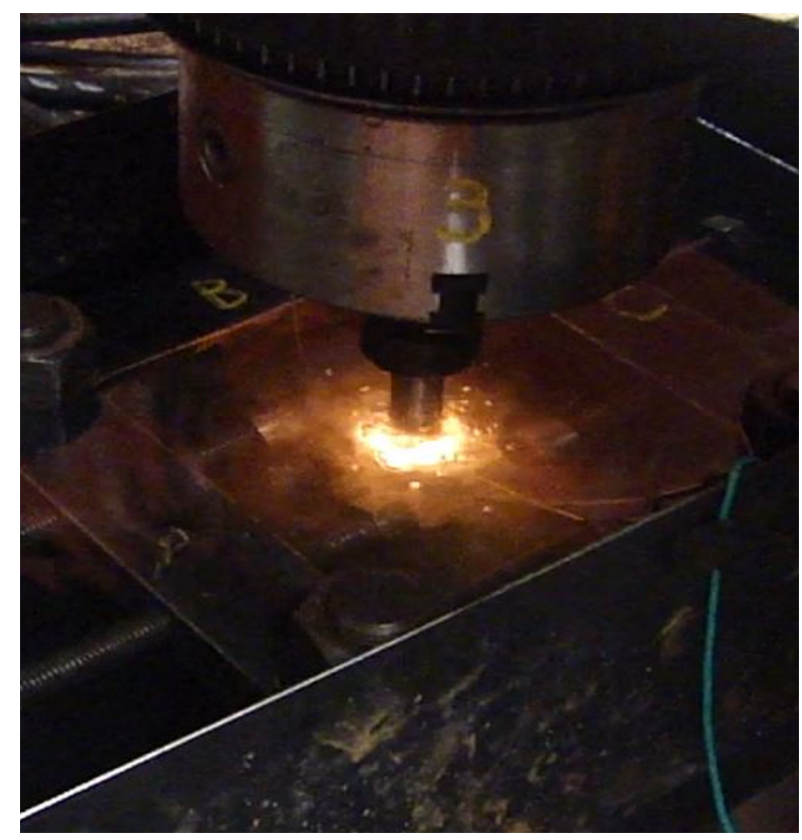

Figure 21. Underwater welding. 

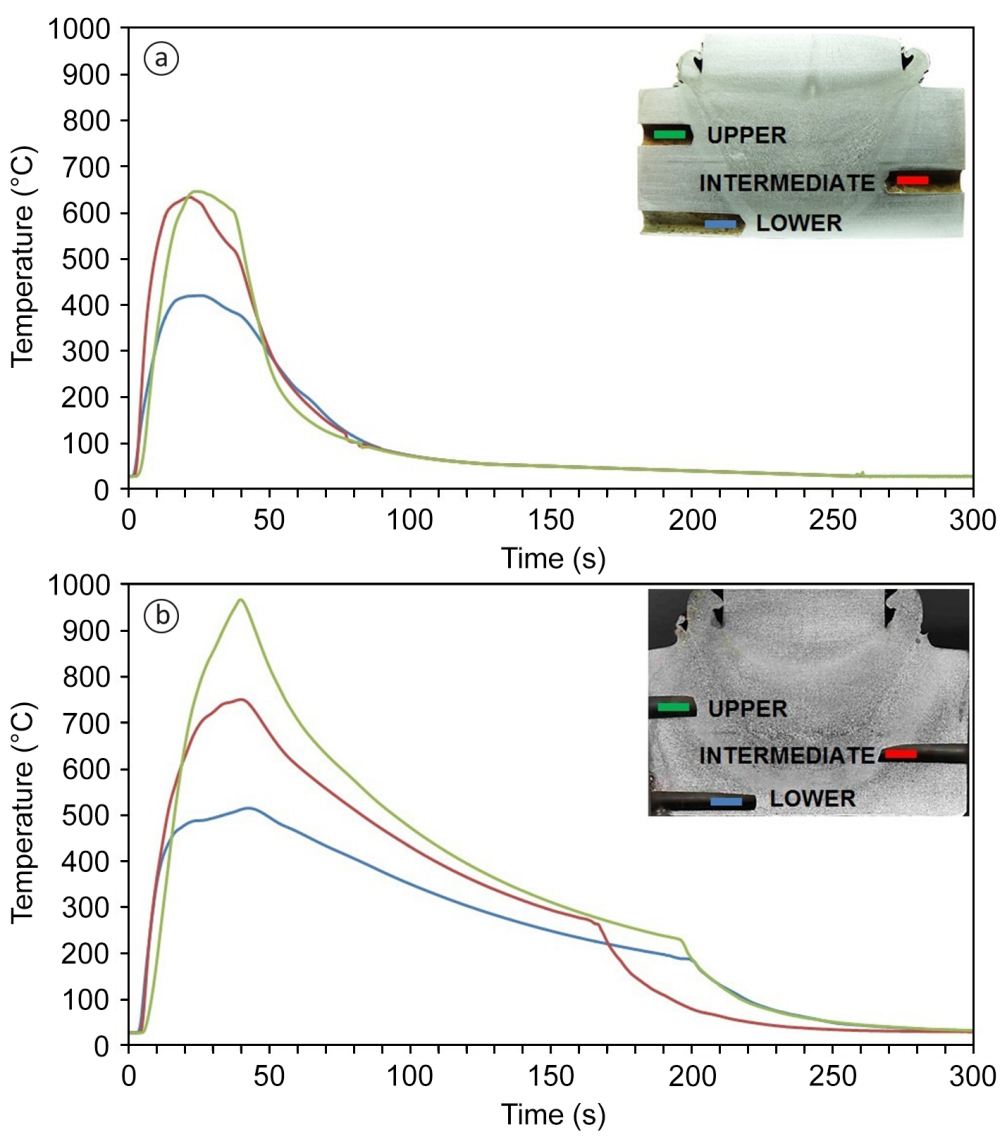

Figure 22. Temperatures of underwater (a) and outdoor (b) welds.

\section{Conclusion}

Studies carried out since 2007 revealed potential of Friction Hydro Pillar Processing for a wide diversity of materials. Joints presented in this paper are the result of research of the parameters and geometry to achieve joints free from defects with metallurgical and mechanical properties appropriate. Due to the unique processing characteristics (without melting, recrystallization and dynamic and static recovery) the joints present unique properties. These welds, even with low weldability material, are produced in less than 6 minutes filling cavities of at least $20 \mathrm{~mm}$ in depth and have great tensile strength, ductility and low thermal influences on the base material. The methods of evaluation of produced joints were carried out using known procedures and tests with the adaptation of specimens to undergo extreme condition. The results obtained are compared with the standards used by industry and, in cases where they do not exist, they are confronted with the requirements of the project.

The development of friction welding equipment, combined with the knowledge of the estimated characteristics of the joint improved utilization of process variables to obtain joints with industrial applicability.

\section{Acknowledgements}

The authors would like to thank the research support of CNPq, Finep, Petrobras and ANP.

\section{References}

[1] Meyer A. Friction Hydro Pillar Processing [master's dissertation]. Hamburg: Technischen Universität Braunschweig; 2002.

[2] Thomas WM, Temple-Smith $P$, inventors. Friction plug extrusion. United Kingdom patent GB 2306365A. 1997 May 7.
[3] Paes MTP. Processamento termomecânico de pinos de aço no interior de cavidades de aço C-Mn através de soldagem por atrito rotacional [doctor thesis]. Rio de Janeiro: Universidade Federal do Rio de Janeiro; 2013. 
[4] Yin Y, Yang X, Cui L, Cao J, Xu W. Investigation on welding parameters and bonding characteristics of underwater wet friction taper plug welding for pipeline steel. International Journal of Advanced Manufacturing Technology. 2015;81(5):851-861. http://dx.doi.org/10.1007/s00170-015-7281-1.

[5] Hating DG, van Zyl C. Temperature distribution for a friction taper stud weld in thick walled $10 \mathrm{Cr} 910$ steel. R \& D Journal of the South Africa Institution of Mechanical Engineering. 2012;28:37-45

[6] Cui L, Yang X, Wang D, Cao J, Xu W. Experimental study of friction taper plug welding for low alloy structure steel: welding process, defects, microestrutures and mechanical properties. Materials \& Design. 2014;62:271-281. http://dx.doi.org/10.1016/j. matdes.2014.05.026

[7] Hattingh DG, Bulbring DLH, Els-Botes A, James MN. Process parameter influence on performance of friction taper stud welds in AISI 4140 steel. Materials \& Design. 2011;32(6):34213430. http://dx.doi.org/10.1016/j.matdes.2011.02.001.

[8] Doubell P, Hattingh DG, Wedderburn IN, Lombard H. Friction welding repair techniques. African Fusion. 2009;16-24.

[9] Pires RR. Efeito da geometria, da força axial e da rotação no reparo por atrito [master's dissertation]. Uberlândia: Universidade Federal de Uberlândia; 2007.

[10] Ambroziak A, Gul B. Investigations of underwater FHPP for welding steel overlap joints. Arcchives of civil and mechanical engineering. 2007;7(2):67-76. http://dx.doi.org/10.1016/S16449665(12)60212-X.

[11] Buzzatti JT, Buzzatti DT, Chludzinski M, Strohaecker TR, Heberle G, Paes MTP, et al. Influência da geometria no processamento de juntas soldadas por atrito com pino consumível. In: Anais do 39을 Congresso Nacional de Soldagem; 2013 Nov. 25-28; Curitiba, Brazil. São Paulo: Associação Brasileira de Soldagem; 2013.

[12] Santos RE, Aguiar F, Meinhardt CP, Strohaecker TR, Marinho RR, Paes MTP. Avaliação de juntas soldadas por atrito com pino consumível. In: Anais do 39o Congresso Nacional de Soldagem; 2013 Nov. 25-28; Curitiba, Brazil. São Paulo: Associação Brasileira de Soldagem; 2013.

[13] Meinhardt CP, Cogo G, Mendonça JG, Chludzinski M, Kwietniesesk CE, Strohaecker TR. Caracterização de solda por fricção com pino consumível em aço inoxidável austenítico UNS S31673 e aço inoxidável dúples USN S31803. In: Anais do 39º Congresso Nacional de Soldagem; 2013 Nov. 25-28; Curitiba, Brazil. São Paulo: Associação Brasileira de Soldagem; 2013.

[14] Chludzinski M. Avaliação da tenacidade à fratura em juntas soldadas por fricção com pino consumível [doctor thesis]. Porto Alegre: Universidade Federal do Rio Grande do Sul; 2014.

[15] Mattei F. Desenvolvimento de equipamento para estudo de soldagem por fricção [master's dissertation]. Porto Alegre: Universidade Federal do Rio Grande do Sul; 2011.

[16] López FS. Montagem e avaliação de uma máquina de solda por fricção [master's dissertation]. Porto Alegre: Universidade Federal do Rio Grande do Sul; 2010.

[17] Meinhardt CP. Caracterização microestrutural de solda por fricção em aço inoxidável austenítico (UNS S31673) e aço inoxidável dúplex (UNS S 31803) [master's dissertation]. Porto Alegre: Universidade Federal do Rio Grande do Sul; 2013. 